\title{
Effect of Aqueous Moringa Oleifera (Lam) Leaf Extracts on Growth Performance and Carcass Characteristics of Hubbard Broiler Chicken
}

\section{-Author(s)}

\author{
Alabi OJ' \\ Malik AD"II \\ $\mathrm{Ng}^{\prime}$ ambi JW" \\ Obaje PIII
}

Ojo BK"II

Research office, University of Limpopo, Private Bag X1106, Sovenga 0727, South Africa

" Department of Agricultural Economics and Animal Production, University of Limpopo, Private Bag X1106, Sovenga 0727, South Africa.

III Department of Animal Production, School of Agriculture and Agricultural Technology, Federal University of Technology, P. M. B 65, Minna Niger State, Nigeria.

\section{Mail Address}

Corresponding author e-mail address Dr Alabi OJ

University of Limpopo, Sovenga, 0727 , South Africa.

Tel: $\quad$ +2349030083008

Email: alabiojgmail.com

\section{- Keywords}

Aqueous, Moringa oleifera, Extracts, Growth Performance, Carcass.

\section{ABSTRACT}

Two hundred and forty day old broiler chicks were used to investigate the effect of aqueous Moringa oleifera leaf extracts (AMOLE) on growth performance and carcass characteristics of broiler chicken. The birds were randomly allocated into six treatments with four replicates, and each replicate containing 10 broiler chicks; the CRD was used. The treatments contained $\mathrm{AMOLE}_{\mathrm{O}_{+}}$(positive control with antibiotic treatment), $\mathrm{AMOLE}_{0-}$ (negative control with ordinary water), $\mathrm{AMOLE}_{60}$ $(60 \mathrm{ml} / \mathrm{l}), \operatorname{AMOLE}_{90}(90 \mathrm{ml} / \mathrm{l}), \mathrm{AMOLE}_{120}(120 \mathrm{ml} / \mathrm{l})$ and $\operatorname{AMOLE}_{150}(150$ $\mathrm{ml} / \mathrm{l})$ inclusion levels of $A M O L E$, respectively. Birds on positive control had the highest final body weight and growth rate $(2392.00 \mathrm{~g}$ and $53.61 \mathrm{~g}$ respectively) and the ones on $150 \mathrm{ml} / \mathrm{l}$ of AMOLE had the least (2042.00 g and $45.37 \mathrm{~g}$ respectively). Results of feed intake showed that birds on positive control had the highest $(84.70 \mathrm{~g})$ and the ones on $90 \mathrm{ml} /$ litre of AMOLE had the lowest (73.19 g); while the results of feed conversion ratio indicated that birds on $A M O L E_{90}$ and AMOLE $_{120}$ performed better than the positive control treatment. Birds on the AMOLE had similar dressing percentages though that of positive control was highest $(94.93 \%)$; while those on $\mathrm{AMOLE}_{60}$ and $\mathrm{AMOLE}_{150}$ had the highest large intestine and lung weights respectively. Aqueous Moringa oleifera leaf extract can be included up to $90 \mathrm{ml} / \mathrm{litre}$ in the drinking water of broiler chicken for reduced feed intake $(12.83 \%)$ and improved feed conversion efficiency (9.11) thus, AMOLE can be used to replace synthetic antibiotics as growth promoter.

\section{INTRODUCTION}

Poultry production remains the most wide spread of all livestock enterprises; it constitutes an important pillar of food security improvement as well as socio-cultural and economic development in most countries (Alders, 2005; Dieye et al., 2010). Broiler production is a source of income, it is a good source of protein and quick returns on investment (Kekocha, 1994). However, the industry in the developing countries is facing some challenges; these challenges include high feed to gain ratio and increase in the cost of feed because of high prices of feed ingredients (Abbas, 2013). Numerous attempts have been made to overcome these challenges, and one of them involves the use of antibiotics in feed. Antibiotics have been utilized as growth promoters and to prevent outbreak of diseases (Thomke \& Elwinger, 1998; Phillips et al., 2004). Furthermore, medication in water using antibiotics helps birds to recover from diseases (Khalafalla et al., 2010). However, the benefit of the use of antibiotics as growth promoters has some disadvantages; these include drug toxicity, residual effects and development of bacteria resistance (Ogbe \& John, 2012). Studies have shown that usage of chloramphenicol resulted into bacteria of the 
genus Salmonella developing resistance to the drug (Gassner \& Wuethrich, 1994). The use of Avilamycin as a growth promoter resulted in an occurrence of avilamycin resistant Enterococcus faecium in broiler farms (Aarestrup, Bager and Andersen, 2000). These problems have led to the ban on the use of antibiotics as growth promoters by the European Union (Butaye et al., 2000; Catalá-Gregori et al., 2008). Thus, attention to safe and natural alternatives such as plants to replace antibiotics (phytobiotics) is on the increase.

Moringa oleifera leaves are reported to have potential prebiotic effects and potentially antioxidant phytochemicals, such as chlorogenic acid and caffeic acid (Siddhuraju and Becker, 2003). Moringa oleifera leaf meal, widely available in many tropical countries, is also a good source of antioxidant compounds such as ascorbic acid, flavonoids, phenolics and carotenoids (Teixeira et al., 2014). The underlying effects of the bioactive compounds in $M$. oleifera leaves are not clear. However, they are believed to induce prebiotic effects, bacterial and immune-stimulant activities (Ghazalah \& Ali, 2008) resulting in increased productivity of broiler chickens. Similar effects have been observed in the presence of antibiotic growth promoters (Khalafalla et al., 2010). However, data on the effects of $M$. oleifera leaf meal (MOLM) extract inclusion in the diet on growth performance and carcass characteristics of broiler chickens is limited and contradictory. Gakuya et al. (2014) reported a decrease in intake but an increase in feed conversion ratio. Olugbemi et al. (2010) observed a reduction in growth performance of broiler chickens when Moringa oleifera leaf meal was beyond $5 \%$ level of inclusion in the feed. Generally, Kakengi et al. (2007), Olugbemi et al. (2010, and Abou-Elezz et al. (2011) agreed that the use of Moringa oleifera leaf meal up to a level of $10 \%$ had no negative effect on the productive performance of broiler chicken, however, levels above $10 \%$ produce adverse effects. This might be because the pure leaf meal are not extracted, tinctured, or cooked as a leaf extract, thus, the birds depend solely on the digestive system to extract the medicinal chemicals from the plant. Furthermore, the low performance at higher inclusion level could be due to high level of anti-nutritional factors and dustiness of MOLM and low digestibility of the fibre, energy and protein presence in the raw leaf (Abba, 2013). Safa \& El-Tazi (2014) observed significant influence of MOLM on all the carcass parameters measured except the thigh weight. There are limited studies of the effect of Moringa oleifera leaf extracts (MOLE) growth performance and carcass characteristics of broiler chickens. Kachik etal. (1992) reported that the presence of phytate and other anti-nutrients can reduce the bioavailability of certain nutrients and processing can be done for maximum utilization of required nutrients from the leaves. Fuglie (1999) reported 53.77, 30.06 and $16.18 \%$ decreased in extracted NDF, ADF and ADL, respectively of MOLE. Makkar \& Becker (1997) reported that significant quantity of anti-nutritional factors, particularly saponins can be removed through solvent and aqueous extractions. Information on this extract is limited. The objective of this study was, therefore, to determine the effect of aqueous Moringa oleifera leaf extracts (AMOLE) on growth performance and carcass characteristics of broiler chickens.

\section{MATERIALS AND METHODS}

\section{Study location}

This study was carried out at the Animal Production Teaching and Research Farm of the Federal University of Technology, Minna, Niger State in Nigeria. Minna is located between latitude $9^{\circ} 37^{\prime}$ North and longitude $6^{\circ} 33^{\prime}$ East. It is located in the Southern Guinea Savanna vegetation zone of North Central Nigeria. The mean monthly minimum and maximum temperatures are $38^{\circ} \mathrm{C}$ and $42^{\circ} \mathrm{C}$ respectively. The mean annual rainfall is between $1200 \mathrm{~mm}-1300 \mathrm{~mm}$ while the mean monthly relative humidity is $65 \%$ (Climatemp, 2011).

\section{Source of the test ingredients and prepa- ration of the extracts}

Fresh Moringa oleifera leaves were purchased between May and June from farmers in Minna. The leaves were air-dried in a laboratory for five days and ground into fine particles using a simple hammer mill. $60 \mathrm{~g}$ of the ground particles were then soaked in one litre of water for 24 hours, and this was done daily. The preparation were then filtered using a muslin cloth to separate the debris from the filtrate, and the extracts were placed in clean containers and diluted using borehole water (volume/volume) to form 0, 60, 90, 120 and $150 \mathrm{ml} / 1000 \mathrm{ml}$ water for Treatments 2 to 5 , respectively. This procedure was carried out daily and the filtrate served to the experimental birds in their drinking water.

\section{Source of the experimental birds, experi- mental diets and experimental design}

A total number of 240 day old Hubbard broiler chicks were purchased from Bnot Harel Hatchery, Oluyole Extension, Ring Road, Ibadan, Oyo State in Nigeria. The birds were randomly allocated to six treatments 
of aqueous Moringa oleifera leaf extracts (AMOLE) in a completely randomized design experimental model. Each of the treatments had four replicates with ten birds per replicate. The birds were acclimatized for one week before being given the experimental treatments. Treatment 1 was the Control of which antibiotics $\left(\right.$ GENDOX $\left.^{\circledR}\right)$ at $1.25 \mathrm{~g} /$ litre was used; Treatment 2, 3, 4, 5 and 6 were given 0,60,90, 120 and $150 \mathrm{ml}$ per litre of aqueous Moringa oleifera leaf extracts (AMOLE) respectively (Table 1).

Table 1 - Aqueous Moringa oleifera leaf extracts treatment levels

\begin{tabular}{lc}
\hline Treatment & Level of inclusion \\
\hline AMOLE $_{0+}$ & Antibiotic $(1.25 \mathrm{~g} /$ litre $)$ \\
AMOLE $_{0-}$ & $0 \mathrm{ml} / /$ \\
AMOLE $_{60}$ & $60 \mathrm{ml} / \mathrm{l}$ \\
AMOLE $_{90}$ & $90 \mathrm{ml} / \mathrm{l}$ \\
AMOLE $_{120}$ & $120 \mathrm{ml} / /$ \\
AMOLE $_{150}$ & $150 \mathrm{ml} / \mathrm{l}$ \\
\hline
\end{tabular}

$\mathrm{ml} / \mathrm{l}=$ Millilitre per litre

$\mathrm{AMOLE}=$ Aqueous Moringa olefeira leaf extracts

\section{Management of the experimental birds}

Twenty four (24) pen units, with an area of a square meter each that could accommodate ten broilers were constructed. The walls and floors of the pens were disinfected with Germicide (IZAL $\left.{ }^{\circledR}\right)$ after washing with detergent and water. Old newspapers spread on wood shavings as litter materials were used for the first one week of the chicks' life. Clean and disinfected feeders and drinkers were set in a place accessible to the birds. Each pen unit was properly labeled for easy identification of each treatment group. In addition, a traditional charcoal pot was placed at a strategic area of each pen unit. The distance of the charcoal pot was adjusted based on the response of chicks to weather condition and rate of feather growth. The charcoal pot was removed during the third week when feathers were fully grown. Super starter mash from TOP FEED ${ }^{\circledR}$ containing a crude protein (CP) content of $26.60 \%$ and metabolizable energy (ME) of $2985 \mathrm{kcal} /$ $\mathrm{kg}$ were given to the birds during the first two weeks, and starter mash (containing $24.85 \%$ CP and 3013 $\mathrm{kcal} / \mathrm{kg} \mathrm{ME}$ ) during the third and fourth week. Finisher feed pellets containing $22.05 \%$ CP and $3026 \mathrm{kcal} /$ $\mathrm{kg} \mathrm{ME}$ were given during the fifth week of age till the sixth week. Feeds were given ad libitum and shifting from one form of feeds to another was done gradually to avoid digestive disorder. Medications and proper vaccinations were given to the birds based on the recommendations of the Nigerian Veterinary Medical Association (NVMA) for this region.

\section{Data collection}

The following data were collected and determined over a period of six weeks.

\section{Water intake $(\mathrm{ml})$}

The drinking water given to the birds in each treatment were measured daily and the left over water were also measured. Water intakes were determined by calculating the difference between the left over and the initial quantity of water given.

\section{Feed intake (g)}

The feed given to the birds in each treatment were weighed daily and the left over feed also weighed. The daily feeds consumed were determined by finding the differences between the left over and the initial quantity of feed given. The weekly records of average feed consumed were obtained for each of the replicate by dividing the total quantity of feed consumed by the total number of chickens in each replicate.

\section{Body weight gain (g)}

The body weight gains for each week were determined by subtracting the previous week's body weight from the current week's body weight. The initial weights of the birds were taken at the commencement of the study. The record obtained was used to calculate the average body weight gain per replicate (the weight for each replicate was added per replicate and then divided by the number of birds in each replicate).

\section{Feed conversion ratio}

The feed conversion ratio (FCR) were determined from the average weight gained and average feed consumed by the birds in each treatment.

Feed conversion ratio $=\frac{\text { average feed intake }(g)}{\text { average body weight gain }(g)}$

\section{Carcass quality examination}

At the end of the experiment, two birds from each replicate were randomly selected and fasted for 18 hours. Live body weight were recorded prior to slaughter. The birds were slaughtered using most humane method "killing cone". After evisceration, the data on hot carcass weights and organ weights were recorded and expressed as a percentage of the live body weights. The eviscerated carcass were chilled at 1- $4{ }^{\circ} \mathrm{C}$ for 24 hours. Then cold carcass weights were determined. The carcasses were partitioned and the breast, wing, thigh, drumsticks and feet yields were 
weighed and expressed as percentage of the cold carcass weight according to the procedure of Hassan et al. (2004).

\section{Chemical analysis}

Proximate composition of the fine powder of Moringa oleifera leaf meal and the phytochemical composition of the leaf meal and the aqueous leaf extract were determined using the procedures of AOAC (2006).

\section{Statistical analysis}

Data collected were subjected to one way analysis of variance (ANOVA) based on the Completely Randomized Design model, using Statistical Analysis System (SAS, 2012). Where differences occurred at $5 \%(p<0.05)$, they were separated using Duncan's Multiple Range Test (SAS, 2012).

\section{RESULTS AND DISCUSSION}

The results of the proximate composition of Moringa oleifera leaf is presented in Table 2. Results obtained in this study show that Moringa oleifera leaf meal has high crude protein content $(23.80 \%)$. This is similar to the result of Nuhu (2010) who reported values of crude protein, ether extract, crude fibre, ash and nitrogen free extracts to be 29.55, 22.30, 19.50 and $7.13 \%$ respectively. It is also similar to the results of Oduro et al. (2008) who reported that Moringa oleifera leaf meal contains $27.51 \%$ CP, $19.25 \%$ CF, $22.3 \%$ EE, 7.13 $\%$ ash and $76.53 \%$ dry matter. Furthermore, crude protein results of $23.80 \%$ obtained in this study is within the 20 to $33 \%$ reported by Foidl \& Paull (2008). However minor differences in the compositions could be due to environmental factors which play a minor role in determining the nutritive value of Moringa oleifera leaf meal.

Table 2 - Proximate composition of Moringa oleifera leaf meal

\begin{tabular}{lc}
\hline Parameters & Percentage composition (\%) \\
\hline Dry matter (DM) & 94.25 \\
Ether extract (EE) & 5.50 \\
Crude protein (CP) & 23.80 \\
Crude fibre (CF) & 16.57 \\
Ash & 9.75 \\
Nitrogen free extracts (NFE) & 38.63 \\
\hline
\end{tabular}

Birds on the $\mathrm{AMOLE}_{0_{+}}$treatment had the highest final body weight (FBW) and daily body weight gain (DBWG). Furthermore, the FBW and DBWG of birds on the aqueous Moringa oleifera leaf treatments increased until $120 \mathrm{ml}$ and then declined; this implies that the optimal dosage must have been reached at about 120 $\mathrm{ml}$ before it declined. The increment in the FBW and DBWG might be as a result of the pharmacological chemical compounds (carbohydrates, saponins, cardiacglycosides, terpenes, steroids, flavonoids and alkaloids) present in the extract as reported by Ambali \& Furo (2012). This result is similar to the report of Zanu et al. (2012) who observed that the FBW and DBWG increased with increase in dosage level until 10 $\%$ and then significantly declined with increasing level of Moringa oleifera leaf meal. Unlike the results from previous researchers (Portugaliza \& Fernandez, 2012, John \& Kenaleone, 2014 and Ashong \& Brown, 2011), birds on the AMOLE treatments had significantly $(p<0.05)$ lower FBW than the control. This might be because Moringa oleifera leaf meal was incorporated in the experimental diet as opposed to the aqueous extracts used in the present study. The antimicrobial (lipophilic compounds) and antioxidant (polyphenols, tannins, anthocyanin, glycosides compound) present in MOLE may attach to the cytoplasmic membrane and remove free radicals, activate antioxidant enzymes, and inhibit oxidases thus, making this elements more available for the birds to use (Jabaeen et al., 2008 and Luqman et al., 2012). Furthermore, the synergy between individual bioactive compounds in MOLM extract may be an important feature of their action which may affect broad aspects of physiology, such as nutrient absorption and processing, red-ox state, or immunity (Wallace et al., 2010; Mbikay, 2012).

Table 3 - Phytochemical composition of Moringa oleifera leaf meal and aqueous leaf extracts

\begin{tabular}{lcc}
\hline & \multicolumn{2}{c}{ Moringa Preparations } \\
\cline { 2 - 3 } Parameter & $\begin{array}{c}\text { Moringa oleifera } \\
\text { leaf meal }\end{array}$ & $\begin{array}{c}\text { Aqueous Moringa } \\
\text { oleifera leaf extracts }\end{array}$ \\
\hline Total flavonoids $(\mu \mathrm{g} / \mathrm{ml})$ & 0.11 & 0.11 \\
Total phenols $(\mu \mathrm{g} / \mathrm{ml})$ & 9.97 & 10.78 \\
Alkaloids $(\mathrm{mg} / \mathrm{ml})$ & 0.26 & 0.21 \\
Tannins $(\mu \mathrm{g} / \mathrm{ml})$ & 1.17 & 5.33 \\
Saponins $(\mu \mathrm{g} / \mathrm{ml})$ & 245.3 & 22.55 \\
\hline
\end{tabular}

Results of feed intake showed that birds on the control treatment had the highest value $(84.70 \mathrm{~g} /$ day $)$, which is an indication that AMOLE inclusion depressed feed intake which might be as a result of nutrient satisfaction. This finding is similar to those of Ashong \& Brown (2011) who reported that the control group had higher feed intake compared to the treatment groups when Moringa oleifera leaf meals were fed to White Leghorn type of chickens. The decrease in feed intake in birds on the AMOLE treatments is also in line with those of Portugaliza \& Fernandez (2012) who observed that Moringa oleifera aqueous leaf extracts in drinking 
water significantly decreased feed intake of broilers as the concentration increased. This could be as a result of improved digestion and metabolism activities of Moringa oleifera (Ghazalah \& Ali, 2008), thus, meeting the nutrients requirements at lower feed intake.
Furthermore, leaves of Moraga oleifera are rich in carotenoids, vitamins, minerals, amino acids, alkaloids, and flavonoids (Siddhuraju \& Becker, 2003). They have rare combination of phenolic compounds (zeatin, quercetin, kaempferol, apigenin), the combination of

Table 4 - Growth performance of broiler chicken administered different levels of aqueous Moringa oleifera leaf extracts in their drinking water for the period of forty two days

\begin{tabular}{|c|c|c|c|c|c|c|c|}
\hline Parameter & $\mathrm{AMOLE}_{0+}$ (Control) & $\mathrm{AMOLE}_{0 .}$ & $\mathrm{AMOLE}_{60}$ & $\mathrm{AMOLE}_{90}$ & AMOLE $_{120}$ & $\mathrm{AMOLE}_{150}$ & SEM \\
\hline Initial body weight (g) & 140.00 & 138.75 & 138.75 & 136.25 & 141.25 & 136.25 & 1.58 \\
\hline Final body weight (g) & $2392.00^{a}$ & $2350.00^{c}$ & $2200.00^{e}$ & $2242.00^{d}$ & $2367.00^{b}$ & $2042.00^{f}$ & 25.29 \\
\hline Daily body weight gain (g) & $53.61^{a}$ & $52.65^{c}$ & $49.08^{e}$ & $50.13^{d}$ & $52.99^{b}$ & $45.37^{f}$ & 0.60 \\
\hline Daily feed intake (g) & $84.70^{\mathrm{a}}$ & $76.34^{\text {bc }}$ & $78.53^{b}$ & $73.19^{c}$ & $79.49^{b}$ & $76.68^{\mathrm{bc}}$ & 3.58 \\
\hline FCR & $1.58^{\mathrm{b}}$ & $1.45^{\mathrm{a}}$ & $1.60^{\mathrm{bc}}$ & $1.46^{\mathrm{a}}$ & $1.50^{\mathrm{ab}}$ & $1.69^{c}$ & 0.03 \\
\hline Water intake (ml) & $516.08^{a}$ & $509.07^{a}$ & $430.89^{b}$ & $498.04^{\mathrm{ab}}$ & $490.39^{\mathrm{ab}}$ & $492.29^{\mathrm{ab}}$ & 11.63 \\
\hline
\end{tabular}

abcdef Means in the same row with different superscripts were significantly different $(p<0.05)$

SEM $=$ Standard error of means

$\mathrm{FCR}=$ Feed conversion ratio

AMOLE = Aqueous Moringa oleifera leaf extracts at different inclusion levels

$\mathrm{AMOLE}_{0+}=$ Positive control (with antibiotic)

$\mathrm{AMOLE}_{0-}=$ Negative control (with ordinary water)

Table 5 - Effect of aqueous Moringa oleifera leaf extracts on carcass characteristics and carcass cut-up parts of Hubbard broilers

\begin{tabular}{|c|c|c|c|c|c|c|c|}
\hline \multirow[b]{2}{*}{ Parameter } & \multicolumn{6}{|c|}{ Treatment } & \multirow[b]{2}{*}{ SEM } \\
\hline & $\mathrm{AMOLE}_{0+}$ (Control) & $\mathrm{AMOLE}_{0-}$ & $\mathrm{AMOLE}_{60}$ & $\mathrm{AMOLE}_{90}$ & AMOLE $_{120}$ & $\mathrm{AMOLE}_{150}$ & \\
\hline Live weight (g) & 2450.00 & 2525.00 & 2250.00 & 2275.00 & 2425.00 & 2300.00 & 46.66 \\
\hline Hot carcass weight (g) & 2325.00 & 2390.00 & 2100.00 & 2075.00 & 2100.00 & 2100.00 & 50.19 \\
\hline Dressing $\%$ & $94.93^{a}$ & $94.67^{a}$ & $93.33^{\mathrm{ab}}$ & $91.23^{\mathrm{ab}}$ & $89.69^{b}$ & $91.26^{\mathrm{ab}}$ & 0.71 \\
\hline Wings (\%) & 10.22 & 10.89 & 10.03 & 9.88 & 10.32 & 9.76 & 0.27 \\
\hline Breast (\%) & 23.55 & 23.95 & 23.32 & 24.17 & 23.72 & 23.89 & 0.43 \\
\hline Thighs (\%) & 14.23 & 14.88 & 14.42 & 12.40 & 13.38 & 11.94 & 0.44 \\
\hline Drumsticks (\%) & 11.20 & 11.80 & 12.20 & 10.99 & 12.40 & 11.94 & 0.26 \\
\hline
\end{tabular}

AMOLE = Aqueous Moringa oleifera leaf extracts

SEM $=$ Standard error of means

Table 6 - Effect of aqueous Moringa oleifera leaf extracts on the visceral organs (\%) of broiler chicken

\begin{tabular}{|c|c|c|c|c|c|c|c|}
\hline \multirow[b]{2}{*}{ Parameter } & \multicolumn{6}{|c|}{ Treatment } & \multirow[b]{2}{*}{ SEM } \\
\hline & $\mathrm{AMOLE}_{0_{+}}$(Control) & $\mathrm{AMOLE}_{0-}$ & $\mathrm{AMOLE}_{60}$ & AMOLE $_{90}$ & AMOLE $_{120}$ & AMOLE $_{150}$ & \\
\hline GIT & 7.10 & 7.37 & 6.98 & 7.75 & 8.13 & 7.73 & 0.22 \\
\hline Proventiculus & 0.31 & 0.25 & 0.31 & 0.25 & 0.26 & 0.30 & 0.01 \\
\hline Crop & 9.00 & 7.82 & 9.65 & 5.30 & 7.65 & 5.25 & 0.64 \\
\hline Gizzard & 1.91 & 1.83 & 2.34 & 2.02 & 1.98 & 2.25 & 0.22 \\
\hline Small intestine & 1.65 & 1.62 & 1.89 & 1.66 & 2.20 & 1.47 & 0.10 \\
\hline Caecum & 9.95 & 6.60 & 7.65 & 9.10 & 10.70 & 11.75 & 0.75 \\
\hline Large intestine & $0.14^{\mathrm{b}}$ & $0.11^{\mathrm{b}}$ & $0.23^{\mathrm{a}}$ & $0.14^{\mathrm{b}}$ & $0.89^{b}$ & $0.15^{b}$ & 0.01 \\
\hline Heart & 0.38 & 0.32 & 0.37 & 0.39 & 0.40 & 0.37 & 0.01 \\
\hline Liver & 1.19 & 1.38 & 1.26 & 1.43 & 1.39 & 1.33 & 0.05 \\
\hline Kidney & 0.23 & 0.16 & 0.27 & 0.33 & 0.11 & 0.22 & 0.03 \\
\hline Lung & $0.24^{b}$ & $0.24^{b}$ & $0.29^{\mathrm{ab}}$ & $0.23^{b}$ & $0.24^{b}$ & $0.31^{\mathrm{a}}$ & 0.01 \\
\hline Spleen & 0.05 & 0.07 & 0.14 & 0.10 & 0.08 & 0.09 & 0.01 \\
\hline Fat & 1.46 & 1.88 & 1.77 & 0.98 & 1.37 & 0.97 & 0.13 \\
\hline
\end{tabular}

SEM $=$ Standard error of means

AMOLE = Aqueous Moringa oleifera leaf extracts

$\mathrm{GIT}=$ Gastrointestinal tract 
these compounds are essential for growth and they reduce disease infestation in the GIT (Teixeira et al., 2014) and, hence, improving the food utilization and leading to less feed needed to meet the requirements for maintenance and production of the birds.

The results of the FCR indicate that the birds on the AMOLE treatments at an inclusion of $90 \mathrm{ml}$ and $120 \mathrm{ml} / \mathrm{l}$ (1.46 and 1.50 respectively) performed better than the control (1.58). This implies that the AMOLE treatments at these levels can be used to replace the antibiotic growth promoter. This might be because of the presence of bioceutical agents in Moringa oleifera plant as reported by Lannaon (2007) and bacterial and immune-stimulant activities of Moringa oleifera plant (Ghazalah \& Ali, 2008). Furthermore, the AMOLE $_{90}$ and $\mathrm{AMOLE}_{120}$ birds gave better FCR than the control, which means better returns on investment. This assertion is supported by David et al. (2012), Safa \& El-Tazi (2012) and Ebenebe et al. (2012) who reported better feed conversion ratio for birds on $M$. Oleifera diets as compared to the control diets.

There was a significant $(p<0.05)$ effect of aqueous Moringa oleifera leaf extracts on the dressing percentage of broiler chicken. This is in line with the results of Aderinola et al. (2013) who studied the effect of Moringa oleifera leaf meal on broiler chicken. Safa \& El-Tazi (2012) also reported a positive influence of Moringa oleifera treatments on rabbit. However, Ayssiwede et al. (2011) and Ochi et al. (2015) who studied the effect of Moringa oleifera seed powder on broiler chickens did not observe significant differences in the dressing percentage among the treatments. The variation could be attributed to the difference in the supplementation form of Moringa oleifera leaf meal. Inclusion of aqueous Moringa oleifera leaf extract showed no significant ( $p>0.05$ ) influence on the weight of the breast meat, thighs, wings and drumsticks. This is in line with the results of Ayssiwede et al. (2011). There were significant differences $(p>0.05)$ in the weight of the large intestine and lungs. The reason for this is not known as AMOLE treatments had no influence on the weight of the other organs in the broiler birds. Similar results were reported by Zanu et al. (2012) and Aderinola et al. (2013).

\section{CONCLUSION}

Aqueous Moringa oleifera leaf extract can be included up to $90 \mathrm{ml} /$ litre in the drinking water of broiler chicken for reduced feed intake $(12.83 \%)$ and improved feed conversion efficiency $(9.11 \%)$ when compared with the control. There was similarity in the thigh weight up to $90 \mathrm{ml} /$ litre inclusion level and there were no significant differences in all the other carcass characteristics measured. It could, therefore, be concluded that Aqueous Moringa oleifera leaf extract can be used to replace synthetic antibiotic as growth promoter. An inclusion level of up to $90 \mathrm{ml} /$ litre is recommended for improved feed conversion.

\section{REFERENCES}

Aarestrup FM, Bager F, Andersen JS. Association between the use of avilamycin for growth promotion and the occurrence of resistance among Enterococcus faecium from broilers epidemiological study and changes over time. Microbiology Drug Resistant 2000;6:71-75

Abbas TE. The use of Moringa oleifera in poultry diets. Turkish Journal of Veterinary and Animal Science 2013;37:492-496.

Abou-Elezz FMK, Sarmiento-Franco L, Santos-Ricalde R, Solorio-Sanchez F. Nutritional effects of dietary inclusion of Leucaena leucocephala and Moringa oleifera leaf meal on Rhode Island Red hens' performance. Cuban Journal of Agricultural Science 2011:45:163-169.

Aderinola OA, Rafium TA, Akinwumi O, Alabi TA, Adeagbo OA. Utilization of Moringa oleifera leaf as feed supplement in broiler diet. Internationa Journal of Food, Agriculture and Veterinary Science 2013;3:94-102.

Alders R. L'aviculture: source de profit et de plaisir. Rome: FAO; 2005.

Ambali AG, Furo NA. An investigation into the phytochemical constituents of Moringa oleifera aqueous root extracts [thesis]. Maiduguri (NIG): Faculty of Veterinary Medicine; 2012

AOAC. Association of Official Analytical Chemists. Official methods of analysis. 18th ed. Washington; 2006

Ashong JO, Brown DL. Safety and efficacy of Moringa oleifera powder for growing poultry. Journal of Animal Science 2011;89:84.

Ayssiwede SB, Dieng A, Bello H, Chrysostome CCAM, Hane MB, et al. Effects of Moringa oleifera (Lam.)leaf meal incorporation in diets on growth performance, carcass and economic characteristics of growing Indigenous Senegal chickens. Pakistan Journal Nutrition 2011;10:1132-45

Butaye PK, Van Damme LA, Devriese L, Van Damme M, Bael S, Haesebrouck F. In vitro susceptibility of Enterococcus faecium isolated from food to growth promoting and therapeutic antibiotics. International Journal of Food Microbiology 2000;54:181-187.

Catalá-Gregori P, Mallet S, Travel A, Lessire M. Efficiency of a prebiotic and a plant extract on broiler performance and intestinal physiology. Proceedings of the 16th European Symposium on Poultry Nutrition; 2002; Strasbourg. France: World Poultry Science Association; 2008.

Climatetemp. Minna climate information [cited 2011]. Available from: http://www.climatetemp.info /nigeria/minna.html.

David LS, Vidanarachchi JK, Samarasinghe K, Cyril HW, Dematawewa CMB. Effects of Moringa oleifera based feed additives on the growth performance and carcass quality of broiler chicken. Tropical Agricultural Research 2012;24(1):12- 20

Dieye PN, Missohou NA, Faye A. L'aviculture familiale: Un levier pouraméliorer les revenus des éleveurspauvres au Sud du Sénégal. In: Faye B, Duteurtre, G., editors. L'élevage, richesse des pauvres. Paris: Editions Quae; 2010. p.191-201. 
Ebenebe $\mathrm{CL}$, Umegechi CO, Nweze BO. Comparison of haematological parameters and weight changes of broiler chicks fed different levels of Moringa oleifera diet. . International Journal of Agriculture and Biological Science 2012;1(1):23-25.

Foidl N, Paull R. Moringa oleifera. In: Janick J, Paull RE. The encyclopedia of fruit and nutrition. Oxfordshire: CABI; 2008. p.509-512.

Fuglie LJ. The Miracle tree: Moringa oleifera: natural nutrition for the tropics. Dakar: Church World Service; 1999. 172 p.

Gakuya DW, Mbugua PN, Kavoi B, Kiama SG. Effect of Supplementation of Moringa oleifera Leaf Meal in Broiler Chicken Feed. International Journal of Poultry Science 2014;13:208-213.

Gakuya DW, Mbugua PN, Kavoi B, Kiama SG. Effect of supplementation of Moringa oleifera leaf meal in broiler chicken feed. International Journal of Poultry Science 2012:13:201-213.

Gassner B, Wuethrich A. Pharmacokinetic and toxicological aspects of the medication of beef type calves with an oral formulation of chloromphenicol palmutate. Journal of Veterinary Pharmacology and Therapeutics 1994;17:279-283.

Ghazalah AA, Ali AM. Rosemary leaves as a dietary supplement for growth in broiler chickens. International Journal of Poultry Science 2008;7(3):234-239.

Hassan II, Askar AA, El-Shourbagy GA. Influence of some medicinal plants on performance, physiological and meat quality traits of broiler chicks. Egypt Poultry Science 2004;24:247-266.

Jabeen R, Shahid M, Jamil A, Ashraf M. Microscopic evaluation of the antimicrobial activity of seed extracts of Moringa oleifera. Pakistan Journal of Botany 2008;40:1349-1358.

John CM, Kenaleone G. Potential use of Moringa oleifera in poultry diets. GJASR 2014;2(2):109-115.

Kachik F, Mudlagiri BG, Gary RB, Joanne H, Lusby WR, Maria BT, et al. Effects of food preparation on qualitative and quantitative distribution of major carotenoids constituents of tomatoes and several green vegetables Journal of Agricultural and Food Chemistry 1992;40:390398.

Kakengi AMV, Kaijage JT, Sarwart SV, Mutayoba SK, Shem MN, Fujihara T. Effect of Moringa leaf meal as a substitute for sunflower seed meal on performance of laying hens in Tanzania. Livestock Research for Rural Development 2007;19(8).

Kekocha CC. Poultry production handbook. London: Macmillan;1994.

Khalafalla MM, Abdellatef E, Dafalla HM, Nassrallah AA, Aboul-Enein $\mathrm{KM}$, Lightfoot DA, et al. Active principle from Moringa oleifera Lam Leaves effective against two leukemias and a hepatocarcinoma. African Journal of Biotechnology 2010;9(49):8467-8471.

Lannaon WJ. Herbal plants as source of antibiotics for broilers. Agriculture Magazine 2007;11(2):55.

Luqman S, Srivastava S, Kumar R, Maurya AK, Chanda D. Experimental assessment of Moringa oleifera leaf and fruit for its antistress, antioxidant and scavenging potential using in vitro and in vivo assays. Evidence-Based Complementary and Alternative Medicine; 2012. Available from: http://dx.doi.org/urn:doi: 10.1155/2012/519084

Makkar HPS, Becker K. Nutrients and anti-quality factors in different morphological parts of the Moringa oleifera tree. Journal of Agricultural Science 1997;128:311-322.
Mbikay M. Therapeutic potential of Moringa oleifera leaves in chronic hyperglycemia and dyslipidemia: A Review. Frontiers in Pharmacology 2012;3(24):1-12.

Nuhu F. Effect of Moringa leaf meal (MOLM) on nutrient digestibility, growth, carcass and blood indices of weaner rabbits [thesis]. Kumasi, Ghana: Kwame Nkurumah University of Science and Technology; 2010.

Ochi EB, Elbushra ME, Fatur M, Abubakr O, Ismail HA. Effect of morin (Moringa oleifera Lam) seeds on the performance and carcass characteristics of broiler chickens. Journal of Natural Sciences Research 2015;5:8

Oduro I, Ellis WO, Owusu D. Nutritional potential of two leaf vegetables: Moringa oleifera and impomea batatas leaves. Scientific. Research and Essay 2008;3(2):57-60.

Ogbe AO, John PA. Proximate study, Mineral and anti-nutrient composition of Moringa oleiferaleaves harvested from Lafia Nigeria potential in poultry nutrition and health. Journal of Microbiology Biotechnology and Food Science 2012;1(3)296-308

Olugbemi TS, Mutayoba SK, Lekule FP. Evaluation of Moringa oleifera leaf meal inclusion in cassava chip based diets fed to laying birds. Livestock Research for Rural Development 2010;22(6). Available from: http:// www.Irrd.org/lrrd22/6/olug22118.htm.

Phillips I, MarkC, Tony C, Brad DG, Christian FRJ, Nightingale C, et al. Does the use of antibiotics in food animals pose a risk to human health? A critical review of published data. Journal of Antimicrobial Chemotherapy 2004;53:28-52.

Portugaliza HP, Fernandez TJ. Growth performance of Cobb broilers given varying concentrations of malunggay (Moringa oleiferalam.) aqueous leaf extract. Journal of Animal and Feed Research 2012;2(6):465-469.

Safa MA, El Tazi. Effect of Feeding Different Levels of Moringao leifera Leaf Meal on the Performance and Carcass Quality of Broiler Chicks. International Journal of Science and Research 2012;3(5):2319-7064

SAS - Statistical Analysis System. SAS user guide: release 9.2. Cary: SAS Institute; 2012.

Siddhuraju P, Becker K. Antioxidant properties of various solvent extracts of total phenolic constituents from three different agroclimatic origins of drumstick tree (Moringa oleifera Lam.) leaves. Journal of Agricultural and Food Chemistry 2003;51 (8)2144-2155.

Teixeira EMB, Carvalho MRB, Neves VA, Silva MA, Arantes-Pereira, L. Chemical characteristics and fractionation of proteins from Moringa oleifera Lam. Leaves. Food Chemistry 2014;147:51-54.

Thomke S, Elwinger K. Growth promotant in feeding pigs and poultry ii;mode of action of antibiotic growth promotants. Annales de Zootechnie 1998;47:153-167

Wallace RJ, Oleszek W, Franz C, Hahn I, Baser KHC, Mathe A, et al.. Dietary plant bioactives for poultry health and productivity. British Poultry Science 2010:51(4):461-487.

Zanu HK, Asiedu P, Tampuori M, Abada M. Asante I. Possibilities of using moringa (Moringa oleifera)leaf meal as a partial substitution for fishmeal in broiler chicken diets. Journal of Animal and Feed Research 2012;2(1)70-75 
